Ksenia KAKAREKO

Uniwersytet im. Adama Mickiewicza, Poznań

\title{
Działalność mniejszości polskiej na Grodzieńszczyźnie
}

$W_{\text {nujacymi w sasiednich republikach ZSRR, wśród białoruskiej mło- }}^{\text {drugiej połowie lat } 80 \text {. }}$ dzieży akademickiej zaczęło gwałtownie wzrastać poczucie świadomości narodowej. Zaczęły pojawiać się pierwsze organizacje, których działalność miała na celu wskrzeszenie białoruskich zwyczajów, zajmowano się badaniem języka i dziedzictwa kulturowego. W latach 1985-1986 w większości dużych miast zostały utworzone organizacje młodzieżowe, które stawiały przed sobą wyłącznie kulturalne, oświatowe lub twórcze zadania. Najbardziej znane są miński klub „Talaka” oraz grodzieński „Pochodnia”. Charakterystyczną cechą tego ruchu młodzieżowego była wyraźna etniczność, która przejawiała się $\mathrm{w}$ wykorzystywaniu języka białoruskiego w życiu codziennym, na posiedzeniach klubów, mityngach, a także w zainteresowaniu historią narodową i kulturą. W drugiej połowie $1987 \mathrm{r}$. powstało na Białorusi kilkaset nieformalnych organizacji młodzieżowych. Ponad $60 \%$ studentów mińskich uczelni wyższych należało do którejś z nieformalnych grup działających w stolicy Białorusi. Równie dynamicznie aktywizowały się środowiska inteligenckie w innych miastach obwodowych na Białorusi. Wkrótce kilkunastoosobowe grupy zaczęły łączyć się w większe organizacje, liczące w 1988 r. nawet po kilkaset członków. Były to przeważnie inteligenckie stowarzyszenia dyskusyjne. Podczas spotkań panowała prawdziwa euforia z powodu nagle otrzymanej wolności słowa. Tysiące osób chciało naprawiać świat komunizmu, nie kwestionując jednak jego fundamentalnych założeń ${ }^{1}$.

Pod wpływem ruchów panujących w tamtym okresie w społeczeństwie białoruskim i przy pomocy Aleksego Karpiuka ${ }^{2}$, pisarza białoru-

${ }^{1}$ O. Łatyszonek, E. Mironowicz, Narodziny suwerennego państwa białoruskiego, w: Historia Białorusi od polowy XVIII do XX w., Białystok 2003, http://autary.iig.pl/mironowicz_e/knihi07-31.htm.

${ }_{2}$ Aleksy Karpiuk (14.04.1920-14.07.1992) - pisarz białoruski. Urodził się we wsi Straszawa woj. białostockie. Skończył dwie klasy polskiego gimnazjum w Wilnie. 
skiego okazującego swoje związki z polskością, garstka ludzi rozpoczęła starania o polskie odrodzenie. Po wielu miesiącach konsultacji i spotkań doszło do założenia w 1988 r. Polskiego Stowarzyszenia Kulturalno-Oświatowego (PSKO) im. Adama Mickiewicza. Zanim powstało PSKO im. A. Mickiewicza władze próbowały namówić założycieli do utworzenia organizacji „kanapowej”, w rodzaju kółka, lub miejskiego stowarzyszenia społeczno-kulturalnego. Jednak od samego początku grupa inicjatywna podkreślała konieczność odrodzenia polskości na Białorusi, nie zgadzając się na proponowane rozwiązania. Założono obwodowe stowarzyszenie, obejmujące swym działaniem cały obwód grodzieński, myśląc o odrodzeniu polskim nie tylko w Grodnie. Po utworzeniu obwodowego Stowarzyszenia Kulturalno-Oświatowego im. Adama Mickiewicza zaczęły powstawać inne oddziały i stowarzyszenia polskie w miastach i wsiach. Często bywało tak, że powstawały one przy pomocy członków PSKO. Oprócz oddziałów w obwodzie grodzieńskim powstały stowarzyszenia w Baranowiczach, Brześciu, Mińsku i innych miejscowościach.

W czerwcu 1990 r. został zwołany I Zjazd Polaków, na którym obwodowe Polskie Stowarzyszenie Kulturalno-Oświatowe im. Adama Mickiewicza zostało przekształcone w Związek Polaków na Białorusi (ZPB), którego przewodniczącym został wybrany jeden z założycieli PSKO Tadeusz Gawin ${ }^{3}$. Stało się to możliwe dzięki przyjęciu ustawy o swobodnym

W latach 1939-1941 studiował na nowogródzkiej uczelni pedagogicznej. W okresie niemieckiej okupacji wchodził w skład podziemia. Podczas akcji dywersyjnej został aresztowany i wysłany do więzienia w Białymstoku, skąd trafił do obozu koncentracyjnego w Stutthof. Jesienią 1943 r. uciekł z obozu i wziął udział w ruchu partyzanckim. W 1944 r. został dowódcą oddziału partyzanckiego im. K. Kalinowskiego na Grodzieńszczyźnie. W latach 1944-1945 służył w radzieckiej armii, uczestniczył w walkach na terenie Polski i Niemiec. Po wojnie ukończył wydział anglistyki na Grodzieńskim Instytucie Pedagogicznym (1949). Pracował jako dyrektor biskupickiej siedmioletniej szkoły w rejonie wołkowyskim, w Grodzieńskim Instytucie Pedagogicznym, w oddziale obwodowym gazety „Grodnienskaja Prawda”, jako korespondent gazety „Literatura i Mastactwa”. W 1961 r. ukończył Wyższe Kursy Literackie w Moskwie. Od $1961 \mathrm{r}$. był kierownikiem agencji „Inturyst”, a od 1965 pełnił funkcję sekretarza grodzieńskiego obwodowego oddziału Związku Pisarzy BSRR. Nagrodzony orderami Czerwonej Flagi, Wojny Ojczyźnianej I i II stopnia, medalami i złotym krzyżem „Virtuti Militari”. Laureat nagrody literackiej ZP BSRR im. I. Mieleża (1986).

3 Tadeusz Gawin (ur. 3 lipca 1951 r. w Grodnie) - publicysta i działacz polonijny, współzałożyciel i pierwszy przewodniczący Związku Polaków na Białorusi w latach 1990-2000, obecnie prezes honorowy ZPB i działacz opozycji demokratycznej na 
rozwoju narodowym obywateli ZSRR zamieszkujących poza granicami swoich organizmów państwowych i narodowościowych lub niemających ich na terenie $Z_{S R R}{ }^{4}$.

Proces powstawania Związku miał charakter długotrwały i trwał około dwóch lat od Zjazdu Założycielskiego w czerwcu 1990 r. Związek został

Białorusi. W 1972 r. ukończył Wyższą Szkołę Oficerską Wojsk Łączności w Orle, a w 1982 r. Wojskową Akademię Łączności w Leningradzie. Początkowo odbywał służbę w wojskach pogranicznych na Dalekim Wschodzie (na Zabajkalu, w Daurii, Nerczyńskim Zawodzie, Dalniereczeńsku oraz we Władywostoku), a od 1987 do 1991 r. pełnił obowiązki szefa łączności jednostki radzieckich wojsk pogranicznych w Grodnie. Odszedł z wojska w stopniu podpułkownika. Był członkiem Partii Komunistycznej ZSRR do roku 1992. W latach 1988-1990 był prezesem Polskiego Kulturalno-Oświatowego Stowarzyszenia im. Adama Mickiewicza, a w latach 1990-2000 przewodniczącym Związku Polaków na Białorusi. Na początku lat dziewięćdziesiątych XX w. był doradcą do spraw narodowościowych przewodniczącego Rady Najwyższej Republiki Białorusi. Po objęciu władzy w 1994 r. przez Aleksandra Lukaszenkę współpracował z A. Łukaszenką, potem zaś opowiedział się po stronie opozycji demokratycznej i wraz z przedstawicielami wszystkich liczących się ugrupowań opozycyjnych podpisał się pod Karta 97, w której zawarto ideę wolnej i demokratycznej Białorusi. Organizował protesty w Grodnie i w Mińsku w 1999 r. przeciwko likwidacji w białoruskich szkołach klas z językiem polskim, a następnie przeciwko innym naruszeniom zasad demokracji w kraju, za co był kilkakrotnie aresztowany i karany grzywnami. Źródło: oficjalna witryna internetowa Związku Polaków na Białorusi (pod przewodnictwem A. Borys), http://www.zpb.org.pl/index.php?id=zpbon.

4 Закон СССР от 26 апреля 1990 г. О свободном национальном развитии граждан СССР, прожсивющих за пределами своих национально-государственных образований или не имеющих их на территории СССР, Свод Законов СССР, 1990, c. 372-391. Ustawę tę można nazwać pierwowzorem wszystkich ustaw o mniejszościach narodowych późniejszych państw Wspólnoty Niepodległych Państw. Po raz pierwszy mówi się w niej o niedopuszczeniu ograniczania i łamania praw przedstawicieli mniejszości narodowych. Przed tym podkreślano, że ZSRR jest wielonarodowym państwem, ale odnosiło się do republik wchodzących w skład Związku. Nie wspominano w żaden sposób o tym, że te republiki także są niejednolite pod względem narodowym, nie uwzględniano mniejszości i ich praw. Ustawę tę można traktować nie tylko jako nowatorskie podejście do struktury społeczeństwa radzieckiego, ale także jako legalne przyzwolenie na tworzenie się sił narodowych, które w dużej mierze przyczyniły się do upadku ZSRR. Ustawa ta zakładała możliwość tworzenia w ramach ZSRR narodowych jednostek administracyjno-terytorialnych. Zapewniano możliwość swobodnego używania języka ojczystego, utworzenia narodowych grup w przedszkolach, narodowych klas i szkół, rozwoju narodowej kultury, tradycji i zwyczajów, otrzymywania informacji w języku ojczystym. Określono ponadto tryb powołania centrów kultury narodowej, stowarzyszeń narodowych, ziomkostw, z zaznaczeniem obowiązku wspierania tych organizacji przez rady deputowanych ludowych. 
zarejestrowany w lutym 1991 r. Jako pierwsza organizacja ludności polskiej wszedł w skład ZPB Stowarzyszenie Kulturalno-Oświatowe „Polonia" z Mińska. Decyzję o przystąpieniu do ZPB na zasadach członka zbiorowego podjęła w kwietniu 1991 r. III obwodowa konferencja PSKO im. A. Mickiewicza z Grodna. Klub Polski w Baranowiczach został przekształcony w grudniu 1991 r. w jeden z rejonowych oddziałów Związku, natomiast w Brzeski Obwodowy Oddział ZPB przekształcił się w marcu 1992 r. w PSKO im. R. Traugutta ${ }^{5}$. Struktury Związku powstawały na terenie całego kraju. Nawet na, wydawałoby się całkowicie zdepolonizowanych represjami i deportacją ludności polskiej jeszcze przed II wojną światową terenach wschodnich Białorusi: Mińszczyźnie, Witebszczyźnie, w Homlu czy Mohylewie. Głównym zadaniem nowopowstałej organizacji było krzewienie języka i promowanie kultury polskiej wśród Polaków mieszkających na Białorusi. Było to spowodowane zanikaniem znajomości języka ojczystego nie tylko wśród młodego pokolenia osób identyfikujących się z polskością, ale także w gronie osób starszych, którzy na skutek polityki rusyfikacyjnej prowadzonej w ciagu wielu lat przez Związek Radziecki odeszli od używania języka polskiego w życiu codziennym.

Podstawowa działalność ZPB prowadzona była prężnie w latach 1991-1994. W 1992 r. już niepodległa Białoruś zawarła z Polską Traktat o Dobrym Sąsiedztwie i Współpracy ${ }^{6}$, który zmienił sytuację mniejszości polskiej na Białorusi dając większe możliwości współpracy z Polską pozwalając na bardziej prężny rozwój polskości i umocnieniu więzi Polaków zamieszkujących na Białorusi z Macierzą. W tym okresie władza

5 S. Mikołajczak, Polacy w życiu politycznym Białorusi w latach 1988-2007, w: Na Obrzeżach Polityki, red. M. Kosman, cz. 5, Poznań 2007, s. 173.

6 Traktat między Rzecząpospolitą Polską a Republiką Białoruś o dobrym sąsiedztwie i przyjaznej współpracy, podpisany w Warszawie dnia 23 czerwca 1992 r., Dz. U. 1993, Nr 118, poz. 527. Traktat reguluje wzajemne zobowiązania dotyczące mniejszości, stwierdza on, że obie strony gwarantują (art. 15) prawo osób należących do mniejszości narodowych do swobodnego zakładania i utrzymywania własnych instytucji, organizacji lub stowarzyszeń oświatowych, kulturalnych i innych, które mogą się ubiegać o pomoc państwa lub inną pomoc oraz będą starały się zapewnić członkom mniejszości odpowiednie możliwości nauczania ich języka ojczystego lub nauczania w tym języku w placówkach oświatowych (art. 16). Na podstawie Traktatu Białoruś wypełnia podstawowe założenia dotyczące mniejszości polskiej, co oznacza tworzenie lekcji języka polskiego, a nawet współpracy przy zakładaniu szkół polskich. Zob. E. Toczek, Polacy na Białorusi i Ukrainie, Kancelaria Sejmu Biuro Studiów i Ekspertyz, luty 1998, nr 599. 
państwowa ze Stanisławem Szuszkiewiczem na czele z dużą dozą entuzjazmu odnosiła się do Związku. Zapadła decyzja polityczna, zgodnie z którą Polacy na Białorusi uzyskali pozwolenie na budowę polskich szkół w Grodnie i Wołkowysku. Nawiązane zostały bliskie związki ZPB ze Stowarzyszeniem „Wspólnota Polska” i Senatem RP. Zaczęto wydawać pisma „Głos znad Niemna” oraz „Magazyn Polski”.

Polacy w Sopoćkinach, Soniczach, Łojkach i innych miejscowościach, gdzie na samym początku powstania Związku zorganizowano nauczanie dzieci w języku polskim, służyli jako przykład dla innych. Ciekawym jest fakt, że ogółem już w 1992 r. języka polskiego uczyło się 10191 dzieci. Wkrótce nie tylko w Sapoćkiniach, ale i w Grodnie, Brześciu, Wołkowysku, Nowogródku zostały zorganizowane klasy z polskim językiem wykładowym.

W ramach Związku Polaków na Białorusi zaczęły funkcjonować takie organizacje jak Polskie Towarzystwo Lekarskie, Towarzystwo Plastyków Polskich, Stowarzyszenie Kombatantów Polskich, Stowarzyszenie Żołnierzy Armii Krajowej, Stowarzyszenie Polaków - Ofiar Represji Politycznych, Towarzystwo Młodzieży Polskiej, Towarzystwo Twórców Ludowych, Klub Sportowy „Sokół”, Klub Inteligencji Polskiej, Republikańskie Zjednoczenie Społeczne „Harcerstwo”, Towarzystwo Młodzieży Polskiej, Chór „Echo Grodna”, Chór „Głos znad Niemna”, Dziecięcy Zespół „Dzwoneczki”, Izba Przemysłowo-Handlowa ZPB, Klub Młodej Polonii „Grodzieńskie Słowiki”, Klub Żeglarski przy Polskiej Szkole w Grodnie, Komitet Pamięci Adama Mickiewicza na Białorusi, Komitet Pamięci Elizy Orzeszkowej na Białorusi, Młodzieżowy Zespół Pieśni i Tańca „Chabry" przy Szkole Polskiej ${ }^{7}$.

W 1995 r. rozpoczęła swoją działalność w Grodnie Polska Macierz Szkolna (dalej PMS), która pojawiła się jako organizacja w pewnym sensie konkurencyjna, a na pewno działająca niezależnie od ZPB. Działa ona także jako organizacja kulturalno-oświatowa. Zajmuje się głównie nauczaniem języka polskiego wśród dzieci i dorosłych, służy metodyczną pomocą nauczycielom języka polskiego na białoruskich uczelniach wyższych. W celu popularyzacji nauczania języka polskiego PMS corocznie jest organizatorem i współorganizatorem szeregu konkursów, przeglądów, festiwali i innych form pracy wśród młodzieży szkolnej. Polska Macierz

7 Oficjalna witryna internetowa Związku Polaków na Białorusi (pod przewodnictwem A. Borys), http://www.zpb.org.pl/index.php?id=zpbs. 
Szkolna od początków istnienia starała się o zakładanie sieci swoich szkół - nie tylko ogólnokształcących. Utworzono Liceum Społeczne Polskiej Macierzy Szkolnej, które mieści się w jej siedzibie. Podobne szkoły założone zostały w Pińsku i Skidlu. Pod zwierzchnictwem PMS działają także Polski Zespół „Lechici”, Klub Kobiet, Uniwersytet Trzeciego Wieku oraz Biblioteka Polska. Wydawany jest miesięcznik „Słowo Ojczyste”8.

Ponadto pojawiły się i nadal działają niezależne od ZPB i PMS mniejsze organizacje polskie nie stawiające sobie za cel tak poważnej misji jak dwie już wspomniane. Są to Klub Polskich Tradycji Narodowych, Towarzystwo Kultury Polskiej Ziemi Lidzkiej, Polskie Towarzystwo Naukowe. Wynika to z różnorodnych zainteresowań członków ZPB, którzy postanowili usamodzielnić się w swojej działalności. Tak Polskie Towarzystwo Naukowe zostało zarejestrowane w 1994 r. Do głównych celów PTN należą: wspieranie naukowej i twórczej działalności członków PTN, sprzyjanie wzmocnieniu przyjaźni, wzajemnego zrozumienia i współpracy pomiędzy naukowcami, twórczymi jednostkami i wszystkimi zainteresowanymi w rozwoju działalności oświatowej i naukowej na Białorusi i w Polsce.

Kolejną organizacją działającą w pełni samodzielnie jest Związek Harcerstwa Polskiego na Białorusi, który uzyskał osobowość prawną w 1997 r. Od 1988 r. i do momentu rejestracji należał on do struktur Związku Polaków na Białorusi. W roku 2000 r. organizacja ta została zarejestrowana ponownie pod nazwą Republikańskie Społeczne Zjednoczenie „Harcerstwo".

Zupełnie inaczej wygląda historia powstania Towarzystwa Kultury Polskiej Ziemi Lidzkiej. Pojawiła się ona w wyniku konfliktu działaczy wewnątrz lidzkiego oddziału ZPB. Doszło do tego, że ówczesny zarząd oddziału ZPB stosunkiem głosów 12:3 nie mógł podjąć żadnej wiążącej decyzji jeżeli przeciw byli prezes, sekretarz i kasjer, którzy mieli poparcie prezesa ZG ZPB. Przed powstaniem nowej polskiej organizacji były prowadzone rozmowy z prezesem Gawinem o rejestracji tej organizacji w ramach Związku Polaków. Niestety, on tej propozycji nie poparł, a do tego członkowie-założyciele TKPZL oraz ich bliska rodzina, absolutnie nie zaangażowana w powstanie nowej organizacji, zostali bezprawnie wyrzuceni z szeregów ZPB. Jedną z przyczyn powstania Towarzystwa było to, że

8 Dane pochodzą z oficjalnej witryny internetowej Polskiej Macierzy Szkolnej, http://www.pmsgrodno.org/. 
lidzcy księża nie akceptowali ówczesnego prezesa oddziału ZPB. Jesienią 1991 r. powstała samodzielna organizacja Towarzystwa Kultury Polskiej Ziemi Lidzkiej. Działalność organizacji głównie skupia się wokół szkolnictwa polskojęzycznego. Od samego początku istnienia Towarzystwo wspiera działalność polskiego harcerstwa jako jednej z najlepszych metod wychowania polskiej młodzieży. Pierwsza drużyna harcerska w Lidzie im. W. Pileckiego powstała przy Towarzystwie już w grudniu $1991 \mathrm{r}$. W 1996 roku harcerze zdecydowali się usamodzielnić - powstało Społeczne Zjednoczenie Harcerstwo Polskie jako niezależna organizacja. Obecnie w Lidzie działa także Koło Żołnierzy Armii Krajowej, założone przez członków Towarzystwa Stanisława Uszakiewicza i Wiktora Nosowicza9.

Zmiany w środowisku Polaków na Białorusi skupionym w głównej mierze wokół ZPB zaczęły się po odejściu T. Gawina ze stanowiska przewodniczącego $^{10}$. V Nadzwyczajny Zjazd ZPB, na którym został wybrany T. Kruczkowski przebiegał $\mathrm{w}$ atmosferze napięć powstałych na tle ideowo-personalnym, źródło których tkwiło w rozbieżnościach ocen sytuacji politycznej na Białorusi ${ }^{11}$. Nowym przewodniczącym został Tadeusz Kruczkowski ${ }^{12}$. Wybory władz nie odbyły się bez skandalu z przywoływaniem

9 A. Kołyszko, Towarzystwo Kultury Ziemi Lidzkiej 1991-1997, witryna internetowa poświęcona historii i kulturze Lidy, http://pawet.net/page1.html.

10 Jako przyczyny swojego odejścia T. Gawin podaje niedobre stosunki z Konsulem Generalnym RP w Grodnie, który był przeciwny walce ZPB o polską szkołę w Nowogródku. Wymienia także starania ze strony władz białoruskich, które czyniły wszystko, by mieć we władzach ZPB osoby lojalne i posłuszne, szczególnie wśród tych, którzy pracowali w państwowych strukturach. Zaznacza także, iż poza tymi przyczynami był on po prostu zmęczony i wyczerpany niepotrzebną walką wewnętrzną w organizacji. Zob. T. Gawin, Polskość na Białorusi, witryna „Wspólnoty Polskiej”, http://www.wspolnota-polska.org.pl/index.php?id=pwko92, 1.03.2009.

11 A. Dworeckow, Sytuacja Polaków oraz problemy polskiej młodzieży na Białorusi, w: Polska mniejszość narodowa w Europie Środkowo-Wschodniej. Nowe problemy $i$ wyzwania wobec współczesnych przemian $w$ państwach regionu, red. Z. J. Winnicki, Wrocław 2005, s. 113-116.

12 Tadeusz Kruczkowski (ur. 5.01.1961 r. w Jaskołdach koło Brzostowicy) - polski i białoruski historyk, działacz mniejszości polskiej na Białorusi, prezes Związku Polaków na Białorusi w latach 2000-2005, wykładowca Uniwersytetu Grodzieńskiego. Uczył się w Liceum Pedagogicznym w Wołkowysku (1976-1980), później studiował historię na Uniwersytecie Grodzieńskim (1983-1988). Po jej ukończeniu przez kilka miesięcy wykładał w Katedrze Historii Uniwersytetu, po czym podjął studia doktoranckie w Instytucie Słowianozawstwa i Bałkanistyki Rosyjskiej Akademii Nauk. W 1993 r. uzyskał stopień doktora za pracę Problematyka polska $w$ rosyjskiej historiografii II połowy XIX wieku. Po powrocie na Białoruś został pracownikiem na- 
przez obie strony - nowego przewodniczącego T. Kruczkowskiego i byłego przewodniczącego T. Gawina - nazwy organizacji, która nie raz będzie argumentem w sporach działaczy polonijnych w Grodnie, a mianowicie KGB. T. Gawin zarzucał T. Kruczkowskiemu zbytnią lojalność, wręcz uległość wobec tej instytucji, a co za tym idzie i wobec reżimu A. Łukaszenki, któremu otwarcie sprzeciwia się T. Gawin. Z drugiej strony przytaczano fakty pracy w przeszłości T. Gawina w tej właśnie instytucji, które obecnie są komentowane jako bezpodstawna prowokacja. Nie są one jednak aż tak bezpodstawne, co stwierdza nawet sam T. Gawin w swoim artykule zamieszczonym w książce Białoruś: trudna droga do demokracji. Rzecz polega na tym, że zgodnie z oficjalną i ogólnodostępną wersją biografii T. Gawina był on oficerem wojsk pogranicza w czasach ZSRR. Każdy znający strukturę wojsk w Związku Radzieckim może bez problemów skojarzyć fakt, że Wojska Pogranicza wchodziły w skład KGB. Z tej racji faktycznie T. Gawin pracował w KGB i jest emerytem $\mathrm{KGB}$, a nie wojskowym. Ten fakt obecnie jest umiejętnie pomijany przez niego i jego sprzymierzeńców.

V Nadzwyczajny Zjazd ZPB wniósł zwrot w działalności Związku i zmienił kierunki jego działalności. Podkreślono, że istotnym celem działalności Związku pozostaje odrodzenie języka polskiego oraz utworzenie szkolnictwa polskojęzycznego. Podniesiono także problem uznania na Białorusi dyplomów polskich uczelni wyższych oraz problem powrotu z Polski na Białoruś byłych studentów, którzy po wieloletnim przebywaniu poza granicami kraju są oderwani od tej rzeczywistości,

ukowym Katedry Historii Powszechnej Uniwersytetu Grodzieńskiego. Od początku lat dziewięćdziesiątych aktywnie brał udział w życiu społeczności polskiej na Białorusi. Od 1997 do 2000 r. stał na czele grodzieńskiego oddziału Polskiego Towarzystwa Naukowego. Honorowo pełnił również funkcję prezesa grodzieńskiego oddziału Związku Polaków na Białorusi. Na V Nadzwyczajnym Zjeździe ZPB w listopadzie 2000 r. został wybrany prezesem organizacji, zastępując Tadeusza Gawina. Niedługo po swoim wyborze na prezesa ZPB oświadczył, że Związek nie będzie popierał żadnej opcji politycznej i będzie się zajmował wyłącznie sprawami polskimi, w tym szczególnie troszczył się o interesy Polaków na Białorusi. Jak twierdzą przeciwnicy Kruczkowskiego, po tym oświadczeniu organizacja zawiesiła wszystkie kontakty z białoruskimi organizacjami pozarządowymi oraz partiami opozycyjnymi. W 2005 r. Tadeusz Kruczkowski przegrał wybory na prezesa ZPB. Za działania na szkodę Rzeczypospolitej Polskiej w 2005 roku Tadeusz Kruczkowski dostał zakaz wjazdu na jej terytorium na 15 lat (według innych źródeł - dożywotnio). Źródło: T. Kruczkowski, Polacy na Biatorusi na tle historii i wspótczesności, Słonim 2003. 
bądź nie chcą wracać z różnych przyczyn, w tym ekonomicznych. Zjazd uchwalił nowe kierunki działań, które zakładały m.in. podjęcie kroków na rzecz zbliżenia i współpracy z Macierzą Szkolna̧, przyjęcie zasady pluralizmu, demokracji i poszanowania zdań wszystkich ludzi. Postanowiono ożywić pracę na rzecz rozwoju szkolnictwa, wykorzystując różne jego dostępne formy oraz rozpatrywać corocznie na posiedzeniach RN stan szkolnictwa. Zdecydowanie postanowiono o zaniechaniu działalności politycznej, gazetę „Głos znad Niemna” postanowiono zorientować na problemy kultury, szkolnictwa i historii oraz zalecono popularyzowanie w prasie osiagnięć białoruskich Polaków.

Główną zmianą w działalności Związku było to, że niedługo po swoim wyborze na prezesa T. Kruczkowski skrytykował upolitycznienie działalności ZPB i oświadczył, że „Związek musi pozostać organizacją społeczno-kulturalną, a nie zajmować się polityką. Oczywiście istnieje pewna racja walki, ale walki o odrodzenie polskości, a nie z władzą tylko z powodu tego, że to jest władza. Ale robić to trzeba nie poprzez rozgrywki polityczne z opozycją, należy rozmawiać z władzą i wymagać przestrzegania naszych praw konstytucyjnych"13. Twierdzi się, że po tym oświadczeniu organizacja zawiesiła wszystkie kontakty z białoruskimi organizacjami pozarządowymi oraz partiami opozycyjnymi. Warto zauważyć, że z wielu przyczyn, których nie sposób tu analizować nie tylko partie opozycyjne nie są szczególnie popierane przez społeczeństwo białoruskie, ale i organizacje pozarządowe. Zarzuca się im, że są finansowane z pieniędzy państw zachodnich i działają często na ich zlecenie, a co za tym idzie propagują poglądy tożsame z opozycyjnymi. Wynikiem odpolitycznienia Związku było znaczące zwiększenie ilości jego członków. Stało się tak, gdyż wcześniej osoby te odstraszał obowiązek uczestniczenia w opozycyjnych akcjach i manifestacjach, za co często grożą rozmaite sankcje ze strony władz. Warto zauważyć, że Grodzieńszczyzna zawsze słynęła jako region w pewnym sensie apolityczny, gdyż jego mieszkańcy nigdy nie wykazywali większego zainteresowania polityką, niezależnie od opcji rządzącej, i zawsze z ostrożnością odnosili się do manifestowania swoich poglądów politycznych. Pod tym względem rozwijanie polskości nie związane z automatycznym opowiadaniem się za pewną opcją polityczną często niezbyt korzystną dla osób pragnących spokojnego życia bez

13 Wypowiedź T. Kruczkowskiego, cyt. Za: A. Dworeckow, Sytuacja Polaków..., s. $117-118$. 
utrudnień ze strony oficjalnych władz, okazała się być o wiele bardziej atrakcyjna. Taka atrakcyjność ZPB zwiększyła się tak w oczach władz białoruskich, jak i polskiej strony, która nie chciała niepotrzebnych konfliktów i nie raz wspierała T. Kruczkowskiego. Szybko stał się on czołową postacią polskiej społeczności na Białorusi. Zrobił też karierę w światowych środowiskach polonijnych. Został wybrany sekretarzem Europejskiej Unii Wspólnot Polonijnych oraz członkiem siedmioosobowej Polonijnej Rady Konsultacyjnej przy Marszałku Senatu RP. Utrzymywał systematyczne stosunki z Senatem RP, Wspólnotą Polską, ministerstwem spraw zagranicznych, występował w telewizji.

Okres od 2000 do 2005 roku można określić jako bardzo owocny w historii działalności ZPB. Powróciło ono do wykonywania głównych założeń statutu, w którym stwierdza się, że głównym celem, który stawia przed sobą Związek, zgodnie z oficjalnie zarejestrowanym statutem, niezmienianym po zaistnieniu konfliktu wewnątrz organizacji, jest sprzyjanie odrodzeniu i rozwojowi kultury polskiej, odrodzeniu narodowemu i kształtowaniu świadomości narodowej ${ }^{14}$. Dla osiagnnięcia tego celu Związek stawia przed sobą następujące zadania: zapewnienie ochrony praw konstytucyjnych oraz interesów prawnych członków Związku, określenie potrzeb i problemów członków Związku, reprezentacja ich interesów w organizacjach państwowych i społecznych, pomoc w tworzeniu w ustalonym przez ustawodawcę trybie, szkół ogólnokształcących, liceów oraz uczelni wyższych z polskim językiem nauczania, propagowanie języka polskiego, zapewnienie jego nauczania w języku polskim, utworzenie w trybie określonym przez ustawodawcę, centrów polskiej kultury na Białorusi, w tym także ze środków ZPB, wspieranie polskiej twórczości literackiej, artystycznej i ludowej, nauka, popularyzacja działalności, osiagnnięć i wkładu do nauki, kultury wybitnych Polaków, w tym wywodzących się z Białorusi, pomoc w ochronie zabytków polskiej historii i kultury, katolickich kościołów i cmentarzy na Białorusi, wychowanie $\mathrm{w}$ duchu patriotyzmu i szacunku do historii, propagowanie tradycji przy-

14 W stwierdzeniu o kształtowaniu świadomości narodowej, w którym nie mówi się o polskiej świadomości można się dopatrywać ostrożnego zapisu pozwalającego na działalność bliską obecnej działalności opozycji białoruskiej, która deklaruje kształtowanie świadomości białoruskiej. Jest ona ich zdaniem niezgodna z ideologią państwową, która tworzy zrusyfikowany obraz Białorusi jako państwa niesamodzielnego nie tylko politycznie, gospodarczo, ale także historycznie, a tym samym skazanego na odwieczny sojusz z Rosją kosztem swojej niepodległości. 
jaźni i współpracy narodów polskiego i białoruskiego, wspólnoty ich losów historycznych, wszechstronne zapoznanie mieszkańców Białorusi z życiem narodu polskiego, jego historią, kulturą, nauką, literaturą, sztuką, twórczością ludową, przeciwdziałanie przejawom szowinizmu, utrudniającym wzajemne porozumienie między obywatelami Białorusi.

Zaczynając od marca 2005 r. wokół Związku Polaków na Białorusi zaczęły rozwijać się wydarzenia, oceniane przez środki społecznego przekazu jako lokalny konflikt polsko-białoruski o podłożu etnicznym oraz jako przejaw geopolitycznych ambicji różnych stron - Warszawy, Waszyngtonu, Moskwy i Mińska. W połowie lata 2005 roku do konfliktu zostały wciagnięte rozmaite społeczne i polityczne organizacje oraz służby dyplomatyczne Białorusi i Polski. Pierwszym z kroków prowadzących do konfliktu wewnątrz ZPB było spotkanie w Baranowiczach grupy zwolenników T. Gawina, na którym ogłoszono o utworzeniu w ramach Związku tzw. „konwersatorium”, czyli grupy opozycyjnie nastawionej do ówczesnego prezesa T. Kruczkowskiego, która mogłaby efektywnie wpływać na przebieg zjazdu, a zwłaszcza na wybory nowych władz tej organizacji. Po czym do regionalnych struktur trafiały osoby nawołujące do agitowania za tym, żeby Andżelika Borys ${ }^{15}$, która została wyłączona ze Związku Polaków za działalność kompromitującą tę organizację ${ }^{16}$, sta-

15 Andżelika Borys (ur. 14 października 1973) - działaczka polonijna na Białorusi, demokratycznie wybrana przewodnicząca Związku Polaków na Białorusi, nie uznawanego przez reżim Aleksandra Łukaszenki. Urodziła się w Grodnie w ówczesnej Białoruskiej SRR. Ukończyła szkołę średnią w grodzieńskiej wiosce Podlipki, a następnie technikum pedagogiczne w Zamościu oraz studia pedagogiczne i psychologiczne w Białymstoku. Po studiach powróciła na Białoruś, by wykładać język polski w polskiej szkole w Grodnie i we wsi Odelsk. Od 1995 r. została członkiem Związku Polaków na Białorusi (ZPB) i w 1998 r. została przewodniczącą wydziału edukacji. Na szóstym zjeździe ZPB w marcu 2005 została, ku zaskoczeniu władz Białorusi, wybrana przewodniczącą Związku, zastępując na tym stanowisku współpracującego z władzami państwowymi Tadeusza Kruczkowskiego. 12 maja Ministerstwo Sprawiedliwości Białorusi unieważniło zjazd. Źródło: http://www.zpb.org.pl/index.php?id=zpbon.

${ }^{16}$ Kierowniczka Domu w Lidzie opowiadała, że już od momentu, kiedy Borys została członkiem Zarządu ZPB, to robiła wszystko, aby sabotować pracę prezesa tej organizacji, pełniącego także funkcję Sekretarza Stowarzyszenia Europejskich Organizacji Polonijnych z siedzibą w Warszawie. Istnieją zdania, że „grupa dywersyjna” pani Borys została przeszkolona do wykonania swej misji w Polsce, także i w Zakopanem, w czasie stażu w redakcji powiązanego z „Gazetą Wyborczą” „Tygodnika Podhalańskiego". M. Głogoczowski, Skad się wzięła ta Andżelika Borys..., blog Związku Polaków na Białorusi, http://by.blox.pl/2006/08/Dr-Marek-Glogoczowski-skad-sie-wziela-ta.html. 
nęła na czele ZPB. Warto zwrócić uwagę na fakt, że obywało się to pod czujnym okiem dyplomaty polskiego Marka Bućko. Także mówi się o okazywaniu psychologicznego przymuszania władz ZPB do dobrowolnego odejścia ze swoich stanowisk, nieuczestniczenia w zjeździe itd. W tych informacjach także można prześledzić obecność M. Bućko ${ }^{17}$.

Źródłem głównego konfliktu, który podzielił społeczność polską był VI Zjazd Związku Polaków, na którym wbrew decyzji Rady Naczelnej ZPB liczba delegatów przewyższała określone normy, a niektórzy delegaci byli podejrzewani o głosowanie nie tylko w swoim imieniu. W stosunku do prezesa T. Kruczkowskiego miały miejsce prowokacje wymagające interwencji milicji. W drugim dniu obrad około dwóch trzecich delegatów wyszło z sali, w której odbywał się zjazd na znak swojego protestu przeciwko formie przebiegu wyborów i sposobom wpływu na wyrażanie ich woli. Jednak nie wpłynęło to na przeprowadzenie wyborów, w wyniku których nowym Prezesem ZPB została A. Borys. Po szeregu skarg do Ministerstwa Sprawiedliwości Białorusi, które wpłynęły od delegatów nieobecnych podczas głosowania, uznało ono wybory VI Zjazdu ZPB za nieważne $^{18}$. Jak wiadomo, w historii państwa istniejącego wcześniej na tych terenach już miały miejsce takie praktyki, które zaobserwowano podczas wyborów A. Borys. Mowa tu o ZSRR, a dokładnie o działalności bolszewików, którzy wykorzystali na swoją korzyść wyjście z sali obrad konkurentów. Czy można w tej sytuacji mówić o demokratycznych wyborach?

W sprawę VI Zjazdu ZPB zaangażowali się nie tylko posłowie polskiego Sejmu, którzy zaproponowali zakazać wjazdu na terytorium Polski białoruskim urzędnikom, sportowcom oraz nie wydawania wiz białoruskim Polakom, którzy nie poparli A. Borys i upolitycznienia ZPB. Zainteresowanie także pojawiło się ze strony USA, które nigdy wcześniej nie interesowały się kwestią przestrzegania praw mniejszości narodowych na Białorusi i traktują ten kraj jako sposób wpływu na Rosję. Wysoki rangą przedstawiciel USA wezwał 14 listopada Europę i Stany Zjednoczone do walki z represjami politycznymi na Białorusi, które - jak powiedział - stają się równie surowe, jak w dawnym Związku Radzieckim. Dyrektor

17 „7 дней”, 4 lipca 2005 г.

18 Zob. A. Верещагина, А. Гурко, Об этнополитических аспектах польско-белорусского конфликта, «Содружуство Независимых Государств», http://eawarn.ru/pub/Bull/WebHome/62_34.htm. 
generalny w Departamencie Stanu USA do spraw europejskich i euroazjatyckich Daniel Fried powiedział w Berlinie, że będzie dyskutować o Białorusi i rządzie prezydenta Aleksandra Łukaszenki w czasie serii spotkań z przedstawicielami władz niemieckich. Stwierdził on, że jest to tragedią dla narodu białoruskiego, a Europa i Stany Zjednoczone powinny uczynić to, co w ich mocy, aby pomóc ${ }^{19}$. W ten sposób można by mówić o tym, że podjęto rozmaite próby, żeby konflikt wokół ZPB przeistoczył się z konfliktu między Polską a Białorusią w konflikt Unii Europejskiej z Białorusią, a może i na jeszcze bardziej globalny.

Po rozpatrzeniu skargi dotyczącej wyników wyborów VII Zjazdu ZPB, która została wniesiona przez członków ZPB i uznaniu przez władze białoruskie wyników Zjazdu za nieważne, został zwołany powtórny zjazd. Odbył się on 27 sierpnia 2005 r. w Wołkowysku. Wybrano na nim większością głosów Józefa Łucznika ${ }^{20}$ na stanowisko przewodniczącego Związku Polaków na Białorusi. Jednak takie rozwiązanie nie było zakończeniem konfliktu w ZPB, lecz okazało się być początkiem regularnej wojny o odcieniu politycznym, wręcz w wymiarze konfliktu międzynarodowego. Grupa kierowana przez A. Borys mając poparcie strony polskiej, zaczęła

19 Apel przedstawiciela USA w sprawie Białorusi, „List Informacyjny EUWP” 2005, nr 10, witryna internetowa Europejskiej Unii Wspólnot Polonijnych, http://www.euwp.org/list1205.html.

20 Józef Łucznik - (ur. 30 listopada 1936 r. w Osocznikach w powiecie augustowskim) - białoruski nauczyciel, działacz mniejszości polskiej na Białorusi, jeden z założycieli Związku Polaków, od 2005 roku jego przewodniczący oficjalnie uznawany przez władze białoruskie. W 1957 roku ukończył Instytut Nauczycielski w Nowej Wilejce, później kształcił się na Wydziale Historycznym Wileńskiego Instytutu Pedagogicznego (do 1964 roku). Nauczał historii w szkole podstawowej w Dajnawie (1957-1964), później pracował jako inspektor szkolny w szkole średniej w Podborzu (1964-1971). W 1971 roku został dyrektorem szkoły podstawowej w Nowosiółkach na Grodzieńszczyźnie, a od 1978 roku stał na czele szkoły średniej w Sopićkiniach. W 1984 roku objął posadę dyrektora szkoły podstawowej w Soniczach. U progu lat dziewięćdziesiątych aktywnie włączył się w polskie odrodzenie narodowe na Białorusi. Wstąpił do Związku Polaków, którego był wiceprzewodniczącym. Wraz z grupą działaczy nie uznał wyboru Andżeliki Borys na przewodniczącą Związku Polaków w marcu 2005 roku. Pięć miesięcy później współorganizował zjazd ZPB w Wołkowysku, podczas którego zgłoszono i przegłosowano jego kandydaturę na prezesa. Władze RP nie uznały wyboru Łucznika na przewodniczącego i zakazały mu wjazdu na teren RP. W latach dziewięćdziesiątych za swoją działalność na Białorusi został odznaczony medalami Józefa Ignacego Kraszewskiego oraz Ministerstwa Edukacji Narodowej RP. Obecnie jest na emeryturze. Ma żonę i dwie córki, które ukończyły studia w Polsce. 
aktywne ataki na kierownictwo wybrane w Wołkowysku, mając do dyspozycji polskie środki społecznego przekazu oraz białoruską prasę opozycyjną.

W połowie marca 2009 roku został przeprowadzony zjazd Związku kierowanego przez A. Borys, który miał na celu wybór nowych władz. Chodziło raczej o reelekcję A. Borys, gdyż innych kandydatur nie rozpatrywano. Polskie środki masowe skupiły na parę dni uwagę na Białorusi w oczekiwaniu prowokacji ze strony władz, działań mających doprowadzić do odwołania zjazdu. Niestety nie ujawniono żadnych działań ze strony milicji, KGB lub jakichkolwiek organów władzy. Obiektywnie rzecz biorąc nie mogło ich być, gdyż nie może mieć większego wpływu zebranie 160 osób w budynku znajdującym się na terenie prywatnym, którzy mają zamiar wybierać władze organizacji, której zgodnie z prawem nie ma.

W trakcie analizy działalności, nieuznawanego przez władze białoruskie, Związku kierowanego przez A. Borys nasuwa się pytanie dotyczące członkostwa w tej organizacji. Wiąże się to m.in. bezpośrednio z art. $193^{1}$ Kodeksu Karnego Białorusi, który przewiduje odpowiedzialność karną za uczestnictwo w nielegalnej (niezarejestrowanej) organizacji społecznej ${ }^{21}$. Budzi wątpliwości czy obecnie deklarowana baza członkowska ZPB A. Borys została w całości przejęta z ZPB sprzed VII Zjazdu, czy były przeprowadzane nowe zapisy do tej organizacji mając na celu skupienie jedynie zwolenników. Ta ostatnia możliwość byłaby sprzeczna z prawem,

${ }^{21}$ Art. $193^{1}$ Kodeksu Karnego Białorusi zakłada, że organizacja działalności lub udział w działalności partii politycznej, innej organizacji społecznej, organizacji religijnej lub fundacji, w stosunku do której została wydana prawomocna decyzja uprawnionych organów państwowych o ich likwidacji albo zwieszeniu ich działalności, jak również organizowanie działalności lub udział w działalności partii politycznej, innej organizacji społecznej, organizacji religijnej lub fundacji, która nie przeszła rejestracji państwowej określonej przez odpowiednią ustawę karane jest grzywną lub aresztem do sześciu miesięcy lub pozbawieniem wolności do lat dwóch. Art. $193^{1}$ pojmuje pod działalnością partii politycznej, innej organizacji społecznej, organizacji religijnej lub fundacji działania skierowane na osiągnięcie celów wskazanych m.in. w statucie lub innych dokumentach tych organizacji. Podkreśla się także w tym artykule, że osobę, która dobrowolnie zaprzestaje działań przewidzianych $\mathrm{w}$ tym artykule i która poinformuje o tym fakcie organy państwowe, zwalnia się od odpowiedzialności karnej, o ile działania te nie wiazzały się z popełnieniem innego przestępstwa. Zasada ta nie dotyczy osób, które dokonały analogicznych działań w ciagu dwóch lat po dobrowolnym ich zaprzestaniu. Zob. Уголовный Кодекс Республики Беларусь, 9 июля 1999 г. N 275-3, Национальный Реестр Правовых Актов 1999 г., № 76, 2/50. 
gdyż takie działania są także zakazane przez art. $193^{1}$ k.k. RB. Przepis ten wyjaśnia także działania władz Białorusi, które przez ZPB A. Borys były uznawane za represje wobec Polaków. Treść art. $193^{1}$ k.k. RB obowiązują wszystkie obywateli Białorusi bez względu na narodowość i poglądy polityczne. Warto także zwrócić uwagę na fakt, że podczas opowieści o wielokrotnych wezwaniach na przesłuchania władz ZPB A. Borys, nigdy nie mówiła o powodach wezwania, mimo że sprawa, w której osoba jest wzywana oraz podstawa prawna wezwania jest wskazana na wezwaniu.

Skłania ku namysłom fakt, że ostatnio rozgorzałe wydarzenia wokół Związku Polaków na Białorusi kierowanego przez A. Borys mają większy wpływ na polską scenę polityczną, aniżeli na sytuację polityczną na Białorusi, zwłaszcza biorąc pod uwagę fakt rozpoczynającego się w Polsce „wyścigu prezydenckiego”. Idąc dalej tym tropem, można by dojść do wniosku, że wydarzenia dotyczące łamania praw Polaków na Białorusi jeżeli nie mają miejsca jedynie w okresie związanym z wyborami w Polsce, to przede wszystkim wtedy są nagłośniane w polskich środkach przekazu. Jest to o tyle dziwne, że można by się było spodziewać aktywności mniejszości polskiej w okresie związanym z wyborami na Białorusi, kiedy to najłatwiej jest zwrócić uwagę międzynarodowej społeczności na sytuację łamania praw mniejszości polskiej.

Związek Polaków na Białorusi nie jest jedyną organizacją skupiającą przedstawicieli polskiej mniejszości. Na Grodzieńszczyźnie prężnie działa wiele organizacji, które nie mają konfliktów z prawem, ani problemów z władzami białoruskimi. Nie oznacza to jednak ,podporządkowania Łukaszence", które jest zarzucane przez stronę polską Związkowi Polaków na Białorusi kierowanemu przez S. Siemaszkę. Przede wszystkim organizacje te stawiają sobie za cel działalność kulturalno-oświatową i stronią od polityki. W ten sposób „nieistniejące” dla zwykłego Polaka organizacje, skupiające wiele tysięcy Polaków zamieszkujących na Grodzieńszczyźnie, spełnia te zadania, które postuluje A. Borys. Pracują one na stworzenie w świadomości społeczeństwa białoruskiego obrazu Polaka, który nie byłby utożsamiany z działaczem opozycji, zdradzającym swoje państwo oficjalnym przyznaniem zwierzchnictwa prezydenta innego państwa, z prowokacjami, łamaniem prawa. Dążą oni do ukazania Polaka zamieszkującego na Grodzieńszczyźnie, jako obywatela Białorusi, patriotę, który jest dumny ze swojego dziedzictwa historycznego i kulturowego, pielęgnującego swój język ojczysty, wzbogacając kulturę współczesnej Białorusi łączącej mieszkańców tak zróżnicowanego obszaru, jakim jest Grodzieńszczyzna w jedną spójną całość. 


\section{Summary}

The national identity of Poles living in the Grodno region began to manifest itself in the early 1990 s as a continuation of the tendency to promote national movements, encouraged by the Soviet Union. After Belarus became independent, Poles have had more opportunities to develop their national culture, and they have began to actively set up numerous minority organizations, open Polish schools and Polish houses, etc. Poles were the most numerous, yet one of many minorities living in the Grodno region, and they have harmoniously integrated with this highly ethnically diversified society. The conflicts emerging within the Union of Poles of Belarus, which receive so much attention in the Polish media, reflect internal conflicts in one of numerous Polish organizations operating in the Grodno region, and they should not affect the situation of all Poles in Belarus. 